\title{
AS PRINCIPAIS TENDÊNCIAS PEDAGÓGICAS NA PRÁTICA ESCOLAR BRASILEIRA E SEUS PRESSUPOSTOS DE APRENDIZAGEM
}

\section{Delcio Barros da Silva}

\section{INTRODUÇÃO}

O objetivo deste artigo é verificar os pressupostos de aprendizagem empregados pelas diferentes tendências pedagógicas na prática escolar brasileira, numa tentativa de contribuir, teoricamente, para a formação continuada de professores.

Sabe-se que a prática escolar está sujeita a condicionantes de ordem sociopolítica que implicam diferentes concepções de homem e de sociedade e, conseqüentemente, diferentes pressupostos sobre o papel da escola e da aprendizagem, inter alia. Assim, justifica-se o presente estudo, tendo em vista que o modo como os professores realizam o seu trabalho na escola tem a ver com esses pressupostos teóricos, explícita ou implicitamente.

Embora se reconheçam as dificuldades do estabelecimento de uma síntese dessas diferentes tendências pedagógicas, cujas influências se refletem no ecletismo do ensino atual, emprega-se, neste estudo, a teoria de José Carlos Libâneo, que as classifica em dois grupos: "liberais" e "progressistas". No primeiro grupo, estão incluídas a tendência "tradicional", a "renovada progressivista", a "renovada não-diretiva" e a "tecnicista". No segundo, a tendência "libertadora", a "libertária" e a "crítico-social dos conteúdos".

Justifica-se, também, este trabalho pelo fato de que novos avanços no campo da Psicologia da Aprendizagem, bem como a revalorização das idéias de psicólogos interacionistas, como Piaget, Vygotsky e Wallon, e a autonomia da escola na construção de sua Proposta Pedagógica, a partir da LDB 9.394/96, exigem uma atualização constante do professor. Através do conhecimento dessas tendências pedagógicas e dos seus pressupostos de aprendizagem, o professor terá condições de avaliar os fundamentos teóricos empregados na sua prática em sala de aula.

No aspecto teórico-prático, ou seja, nas manifestações na prática escolar das diversas tendências educacionais, será dado ênfase ao ensino da Língua Portuguesa, considerando-se as diferentes concepções de linguagem que perpassam esses períodos do pensamento pedagógico brasileiro.

\section{TENDÊNCIAS PEDAGÓGICAS LIBERAIS}

Segundo LIBÂNEO (1990), a pedagogia liberal sustenta a idéia de que a escola tem por função preparar os indivíduos para o desempenho de papéis sociais, de acordo com as aptidões individuais. Isso pressupõe que o indivíduo precisa 
adaptar-se aos valores e normas vigentes na sociedade de classe, através do desenvolvimento da cultura individual. Devido a essa ênfase no aspecto cultural, as diferenças entre as classes sociais não são consideradas, pois, embora a escola passe a difundir a idéia de igualdade de oportunidades, não leva em conta a desigualdade de condições.

\subsection{TENDÊNCIA LIBERAL TRADICIONAL}

Segundo esse quadro teórico, a tendência liberal tradicional se caracteriza por acentuar o ensino humanístico, de cultura geral. De acordo com essa escola tradicional, o aluno é educado para atingir sua plena realização através de seu próprio esforço. Sendo assim, as diferenças de classe social não são consideradas e toda a prática escolar não tem nenhuma relação com o cotidiano do aluno.

Quanto aos pressupostos de aprendizagem, a idéia de que o ensino consiste em repassar os conhecimentos para o espírito da criança é acompanhada de outra: a de que a capacidade de assimilação da criança é idêntica à do adulto, sem levar em conta as características próprias de cada idade. A criança é vista, assim, como um adulto em miniatura, apenas menos desenvolvida.

No ensino da língua portuguesa, parte-se da concepção que considera a linguagem como expressão do pensamento. Os seguidores dessa corrente lingüística, em razão disso, preocupam-se com a organização lógica do pensamento, o que presume a necessidade de regras do bem falar e do bem escrever. Segundo essa concepção de linguagem, a Gramática Tradicional ou Normativa se constitui no núcleo dessa visão do ensino da língua, pois vê nessa gramática uma perspectiva de normatização lingüística, tomando como modelo de norma culta as obras dos nossos grandes escritores clássicos. Portanto, saber gramática, teoria gramatical, é a garantia de se chegar ao domínio da língua oral ou escrita.

Assim, predomina, nessa tendência tradicional, o ensino da gramática pela gramática, com ênfase nos exercícios repetitivos e de recapitulação da matéria, exigindo uma atitude receptiva e mecânica do aluno. Os conteúdos são organizados pelo professor, numa seqüência lógica, e a avaliação é realizada através de provas escritas e exercícios de casa.

\subsection{TENDÊNCIA LIBERAL RENOVADA PROGRESSIVISTA}

Segundo essa perspectiva teórica de Libâneo, a tendência liberal renovada (ou pragmatista) acentua o sentido da cultura como desenvolvimento das aptidões individuais.

A escola continua, dessa forma, a preparar o aluno para assumir seu papel na sociedade, adaptando as necessidades do educando ao meio social, por isso ela deve imitar a vida. Se, na tendência liberal tradicional, a atividade pedagógica estava centrada no professor, na escola renovada progressivista, defende-se a idéia de "aprender fazendo", portanto centrada no aluno, valorizando as tentativas 
experimentais, a pesquisa, a descoberta, o estudo do meio natural e social, etc, levando em conta os interesses do aluno.

Como pressupostos de aprendizagem, aprender se torna uma atividade de descoberta, é uma auto-aprendizagem, sendo o ambiente apenas um meio estimulador. Só é retido aquilo que se incorpora à atividade do aluno, através da descoberta pessoal; o que é incorporado passa a compor a estrutura cognitiva para ser empregado em novas situações. É a tomada de consciência, segundo Piaget.

No ensino da língua, essas idéias escolanovistas não trouxeram maiores conseqüências, pois esbarraram na prática da tendência liberal tradicional.

\subsection{TENDÊNCIA LIBERAL RENOVADA NÃO-DIRETIVA}

Acentua-se, nessa tendência, o papel da escola na formação de atitudes, razão pela qual deve estar mais preocupada com os problemas psicológicos do que com os pedagógicos ou sociais. Todo o esforço deve visar a uma mudança dentro do indivíduo, ou seja, a uma adequação pessoal às solicitações do ambiente.

Aprender é modificar suas próprias percepções. Apenas se aprende o que estiver significativamente relacionado com essas percepções. A retenção se dá pela relevância do aprendido em relação ao "eu", o que torna a avaliação escolar sem sentido, privilegiando-se a auto-avaliação. Trata-se de um ensino centrado no aluno, sendo o professor apenas um facilitador. No ensino da língua, tal como ocorreu com a corrente pragmatista, as idéias da escola renovada não-diretiva, embora muito difundidas, encontraram, também, uma barreira na prática da tendência liberal tradicional.

\subsection{TENDÊNCIA LIBERAL TECNICISTA}

A escola liberal tecnicista atua no aperfeiçoamento da ordem social vigente (o sistema capitalista), articulando-se diretamente com o sistema produtivo; para tanto, emprega a ciência da mudança de comportamento, ou seja, a tecnologia comportamental. Seu interesse principal é, portanto, produzir indivíduos "competentes" para o mercado de trabalho, não se preocupando com as mudanças sociais.

Conforme MATUI (1988), a escola tecnicista, baseada na teoria de aprendizagem S-R, vê o aluno como depositário passivo dos conhecimentos, que devem ser acumulados na mente através de associações. Skinner foi o expoente principal dessa corrente psicológica, também conhecida como behaviorista. Segundo RICHTER (2000), a visão behaviorista acredita que adquirimos uma língua por meio de imitação e formação de hábitos, por isso a ênfase na repetição, nos drills, na instrução programada, para que o aluno for me "hábitos" do uso correto da linguagem.

A partir da Reforma do Ensino, com a Lei 5.692/71, que implantou a escola tecnicista no Brasil, preponderaram as influências do estruturalismo lingüístico e a 
concepção de linguagem como instrumento de comunicação. A língua - como diz TRAVAGLIA (1998) - é vista como um código, ou seja, um conjunto de signos que se combinam segundo regras e que é capaz de transmitir uma mensagem, informações de um emissor a um receptor. Portanto, para os estruturalistas, saber a língua é, sobretudo, dominar o código.

No ensino da Língua Portuguesa, segundo essa concepção de linguagem, o trabalho com as estruturas lingüísticas, separadas do homem no seu contexto social, é visto como possibilidade de desenvolver a expressão oral e escrita. A tendência tecnicista é, de certa forma, uma modernização da escola tradicional e, apesar das contribuições teóricas do estruturalismo, não conseguiu superar os equívocos apresentados pelo ensino da língua centrado na gramática normativa. Em parte, esses problemas ocorreram devido às dificuldades de o professor assimilar as novas teorias sobre o ensino da língua materna.

\section{TENDÊNCIAS PEDAGÓGICAS PROGRESSISTAS}

Segundo Libâneo, a pedagogia progressista designa as tendências que, partindo de uma análise crítica das realidades sociais, sustentam implicitamente as finalidades sociopolíticas da educação.

\subsection{TENDÊNCIA PROGRESSISTA LIBERTADORA}

As tendências progressistas libertadora e libertária têm, em comum, a defesa da autogestão pedagógica e o antiautoritarismo. A escola libertadora, também conhecida como a pedagogia de Paulo Freire, vincula a educação à luta e organização de classe do oprimido. Segundo GADOTTI (1988), Paulo Freire não considera o papel informativo, $o$ ato de conhecimento na relação educativa, mas insiste que o conhecimento não é suficiente se, ao lado e junto deste, não se elabora uma nova teoria do conhecimento e se os oprimidos não podem adquirir uma nova estrutura do conhecimento que lhes permita reelaborar e reordenar seus próprios conhecimentos e apropriar-se de outros.

Assim, para Paulo Freire, no contexto da luta de classes, o saber mais importante para o oprimido é a descoberta da sua situação de oprimido, a condição para se libertar da exploração política e econômica, através da elaboração da consciência crítica passo a passo com sua organização de classe. Por isso, a pedagogia libertadora ultrapassa os limites da pedagogia, situando-se também no campo da economia, da política e das ciências sociais, conforme Gadotti.

Como pressuposto de aprendizagem, a força motivadora deve decorrer da codificação de uma situação-problema que será analisada criticamente, envolvendo o exercício da abstração, pelo qual se procura alcançar, por meio de representações da realidade concreta, a razão de ser dos fatos. Assim, como afirma Libâneo, aprender é um ato de conhecimento da realidade concreta, isto é, da situação real vivida pelo educando, e só tem sentido se resulta de uma aproximação crítica dessa realidade. Portanto o conhecimento que o educando transfere representa uma resposta à situação de opressão a que se chega pelo 
processo de compreensão, reflexão e crítica.

No ensino da Leitura, Paulo Freire, numa entrevista, sintetiza sua idéia de dialogismo: "Eu vou ao texto carinhosamente. De modo geral, simbolicamente, eu puxo uma cadeira e convido o autor, não importa qual, a travar um diálogo comigo".

\subsection{TENDÊNCIA PROGRESSISTA LIBERTÁRIA}

A escola progressista libertária parte do pressuposto de que somente o vivido pelo educando é incorporado e utilizado em situações novas, por isso o saber sistematizado só terá relevância se for possível seu uso prático. A ênfase na aprendizagem informal, via grupo, e a negação de toda forma de repressão, visam a favorecer o desenvolvimento de pessoas mais livres. No ensino da língua, procura valorizar o texto produzido pelo aluno, além da negociação de sentidos na leitura.

\subsection{TENDÊNCIA PROGRESSISTA CRÍTICO-SOCIAL DOS CONTEÚDOS}

Conforme Libâneo, a tendência progressista crítico-social dos conteúdos, diferentemente da libertadora e libertária, acentua a primazia dos conteúdos no seu confronto com as realidades sociais. A atuação da escola consiste na preparação do aluno para o mundo adulto e suas contradições, fornecendo-lhe um instrumental, por meio da aquisição de conteúdos e da socialização, para uma participação organizada e ativa na democratização da sociedade.

Na visão da pedagogia dos conteúdos, admite-se o princípio da aprendizagem significativa, partindo do que o aluno já sabe. A transferência da aprendizagem só se realiza no momento da síntese, isto é, quando o aluno supera sua visão parcial e confusa e adquire uma visão mais clara e unificadora.

\section{TENDÊNCIAS PEDAGÓGICAS PÓS-LDB 9.394/96}

Após a Lei de Diretrizes e Bases da Educação Nacional de n. ${ }^{\circ}$ 9.394/96, revalorizam-se as idéias de Piaget, Vygotsky e Wallon. Um dos pontos em comum entre esses psicólogos é o fato de serem interacionistas, porque concebem o conhecimento como resultado da ação que se passa entre o sujeito e um objeto. De acordo com ARANHA (1998), o conhecimento não está, então, no sujeito, como queriam os inatistas, nem no objeto, como diziam os empiristas, mas resulta da interação entre ambos.

Para citar um exemplo no ensino da língua, segundo essa perspectiva interacionista, a leitura como processo permite a possibilidade de negociação de sentidos em sala de aula. O processo de leitura, portanto, não é centrado no texto, ascendente, bottom-up, como queriam os empiristas, nem no receptor, descendente, top-down, segundo os inatistas, mas ascendente/descendente, ou seja, a partir de uma negociação de sentido entre enunciador e receptor. Assim, nessa abordagem interacionista, o receptor é retirado da sua condição de mero objeto do sentido do texto, de alguém que estava ali para decifrá-lo, decodificá-lo, 
como ocorria, tradicionalmente, no ensino da leitura.

As idéias desses psicólogos interacionistas vêm ao encontro da concepção que considera a linguagem como forma de atuação sobre o homem e o mundo e das modernas teorias sobre os estudos do texto, como a Lingüística Textual, a Análise do Discurso, a Semântica Argumentativa e a Pragmática, entre outros.

\section{CONSIDERAÇÕES FINAIS}

De acordo com esse quadro teórico de José Carlos Libâneo, deduz-se que as tendências pedagógicas liberais, ou seja, a tradicional, a renovada e a tecnicista, por se declararem neutras, nunca assumiram compromisso com as transformações da sociedade, embora, na prática, procurassem legitimar a ordem econômica e social do sistema capitalista. No ensino da língua, predominaram os métodos de base ora empirista, ora inatista, com ensino da gramática tradicional, ou sob algumas as influências teóricas do estruturalismo e do gerativismo, a partir da Lei 5.692/71, da Reforma do Ensino.

Já as tendências pedagógicas progressistas, em oposição às liberais, têm em comum a análise crítica do sistema capitalista. De base empirista (Paulo Freire se proclamava um deles) e marxista (com as idéias de Gramsci), essas tendências, no ensino da língua, valorizam o texto produzido pelo aluno, a partir do seu conhecimento de mundo, assim como a possibilidade de negociação de sentido na leitura.

A partir da LDB 9.394/96, principalmente com as difusão das idéias de Piaget, Vygotsky e Wallon, numa perspectiva sócio-histórica, essas teorias buscam uma aproximação com modernas correntes do ensino da língua que consideram a linguagem como forma de atuação sobre o homem e o mundo, ou seja, como processo de interação verbal, que constitui a sua realidade fundamental.

\section{BIBLIOGRAFIA}

ARANHA, Maria Lúcia de Arruda. Filosofia da Educação. São Paulo : Editora Moderna, 1998.

COSTA, Marisa Vorraber et al. O Currículo nos Limiares do Contemporâneo. Rio de Janeiro : DP\&A editora, 1999.

GADOTTI, Moacir. Pensamento Pedagógico Brasileiro. São Paulo : Ática, 1988.

LIBÂNEO, José Carlos. Democratização da Escola Pública. São Paulo : Loyola, 1990.

MATUI, Jiron. Construtivismo. São Paulo : Editora Moderna, 1998.

RICHTER, Marcos Gustavo. Ensino do Português e Interatividade. Santa Maria : Editora da UFSM, 2000.

TRAVAGLIA, Luiz Carlos. Gramática e Interação. São Paulo : Cortez, 1998. 